RECONCEIVING

THE

GeNE 



\section{Reconceiving the Gene}

Seymour Benzer's Adventures in Phage Genetics

Frederic Lawrence Holmes

Edited by William C. Summers

Yale University Press

New Haven \& London 
Copyright (C) 2006 by Yale University.

All rights reserved.

This book may not be reproduced, in whole or in part, including illustrations, in any form (beyond that copying permitted by Sections 107 and 108 of the U.S. Copyright Law and except by reviewers for the public press), without written permission from the publishers.

Designed by James J. Johnson and set in Melior Roman types by Keystone Typesetting.

Printed in the United States of America.

\section{Library of Congress Cataloging-in-Publication Data}

Holmes, Frederic Lawrence.

Reconceiving the gene : Seymour Benzer's adventures in phage genetics / Frederic Lawrence Holmes ; edited by William C. Summers.

p. ; cm.

Includes bibliographical references and index.

ISBN-13: 978-0-300-11078-4 (cloth : alk. paper)

ISBN-10: 0-300-11078-2 (cloth : alk. paper)

1. Benzer, Seymour. 2. Geneticists-United States-Biography. 3. BacteriophagesGenetics. 4. Viral genetics-History. I. Summers, William C. II. Title.

[DNLM: 1. Benzer, Seymour. 2. Bacteriophage T4-genetics. 3. Genetics, MicrobialBiography. 4. Chromosome Mapping. 5. Genome, Bacterial. WZ 100 B4786h 2006] QH429.2.S49 2006

$576.5092-\mathrm{dc} 22$

[B]

2005033010

A catalogue record for this book is available from the British Library.

The paper in this book meets the guidelines for permanence and durability of the Committee on Production Guidelines for Book Longevity of the Council on Library Resources.

10

9

8

76

5

3

21 